\title{
Turning the tide: Registered nurses' job withdrawal intentions in a Finnish university hospital
}

\author{
Author: \\ Hanna M. Salminen ${ }^{1}$ \\ Affiliation: \\ ${ }^{1}$ School of Business and \\ Economics, University of \\ Jyväskylä, Finland \\ Correspondence to: \\ Hanna Salminen \\ Email: \\ hanna.m.salminen@jyu.fi \\ Postal address: \\ PO Box 35, FIN-40014, \\ Finland \\ Dates: \\ Received: 21 Sept. 2011 \\ Accepted: 13 Dec. 2011 \\ Published: 17 Feb. 2012 \\ How to cite this article: \\ Salminen, H.M. (2012). \\ Turning the tide: Registered \\ nurses' job withdrawal \\ intentions in a Finnish \\ university hospital. SA \\ Journal of Human Resource \\ Management/SA Tydskrif vir \\ Menslikehulpbronbestuur, \\ 10(2), Art. \#410, 11 pages. \\ http://dx.doi.org/10.4102/ \\ sajhrm.v10i2.410
}

(C) 2012. The Authors. Licensee: AOSIS OpenJournals. This work is licensed under the Creative Commons Attribution License.
Orientation: Given the global shortage of registered nurses, it is important to investigate the intentions for job withdrawal of nurses, and resolve these, in order to retain nurses in the field.

Research purpose: The objective was to examine the intentions for job withdrawal of ageing and younger nurses, and the antecedents of these intentions, with special reference to job control and perceived development opportunities. The age of 45 was adopted as a starting point when referring to ageing employees.

Motivation for the study: Different forms of job withdrawal have rarely been studied together and associated.

Research design, approach and method: A quantitative study was applied with logistic regression analyses. Respondents were registered nurses working in a university hospital in Finland. The response rate was $46.1 \%(N=343)$.

Main findings: A quarter (25\%) of the nurses had frequently thought about leaving the profession and $19 \%$ of the nurses had thought about taking early retirement. Factors that increased the likelihood of intentions for occupational turnover were young age, low job satisfaction, low organisational commitment, low work ability and skills in balance with or above present work demands. The intention to take early retirement was increased with older age, being male, working shifts, low work ability, low job satisfaction and poor job control.

Practical/managerial implications: A nurse's job satisfaction and work ability should be regularly monitored and opportunities should be offered them, to apply their skills and to control their work, in order to retain them.

Contribution/value-added: The article added information about the factors that contribute to a nurse's intentions for job withdrawal.

\section{Introduction \\ Key focus of the study}

Finland is one of the fastest-ageing societies in the world (Tuominen, 2007). Therefore Finland, like many other countries, is facing 'a demographic double whammy', these being an ageing nursing workforce coupled with greater demands for health care services because of the ageing population (Armstrong-Stassen \& Schlosser, 2010; Buchan \& Calman, 2004). There is already a substantial shortage of registered nurses in many countries, resulting from the ageing nursing workforce, the number of nurses who leave the profession prematurely and the decline in the number of young people entering the nursing profession (Blakeley \& Ribeiro, 2008; Estryn-Behar, Van der Heijden, Fry \& Hasselhorn, 2010). Compared to other occupational groups, nurses tend to leave their profession in much greater numbers (Van der Heijden, Van Dam \& Hasselhorn, 2009). The Nurses Early Exit (NEXT) study $(N=25$ 324), conducted in 10 European countries (Belgium, Germany, Finland, France, Great Britain, Italy, Netherlands, Norway, Poland and Slovakia), showed that $14 \%$ of nurses had frequently thought about giving up nursing (Hasselhorn, Müller \& Tackenberg, 2005). The intention of Finnish nurses to leave their profession has varied in different studies, from 15\% (Laine, 2005) to over 30\% (Hintsala, 2005; Kuokkanen, Leino-Kilpi \& Katajisto, 2003). Occupational turnover concerns young nurses in particular. For example, a recent study showed that $26 \%$ of young (under 30 years old) Finnish nurses have often thought about giving up nursing (Flinkman, Laine, Leino-Kilpi, Hasselhorn \& Salanterä, 2008).

Nurses also tend to retire before the standard retirement age (Blakeley \& Ribeiro, 2008). In Finland, the number of nurses per capita is the highest in Europe, but the nursing population is relatively old (Flinkman et al., 2008). According to a recent study, Finnish nurses generally wish to retire at about the age of 59 (Eskola, 2007). The Finnish pension system was reformed in 2005 
in order to increase participation in the labour force amongst older employees. Since these reforms, employees have had the option to retire between the age of 63 and 68. Employees can also retire at the age of 62 , but then their pension is permanently lower than the normal pension (Hietaniemi \& Ritola, 2007).

In this article, the intentions for job withdrawal are studied with special reference to perceived development opportunities and job control. The rationale for this is that both development opportunities and job control have been presented as important examples of incentives relating to the nurses' retention strategies (Hayes et al., 2006; LavoieTremblay, O’Brien-Pallas, Viens, Brabant \& Gélinas, 2006). In this study the intentions of the nurses are used to reflect their actual decision to leave the job, because previous studies have shown that the intention towards job withdrawal is a powerful predictor of the actual event (Adams \& Beehr, 1998; Beehr, 1986; Flinkman, Leino-Kilpi \& Salanterä, 2010). By identifying the factors associated with an employee's intention for job withdrawal, preventive actions could be taken before he or she actually withdraws from the job.

The next section presents the theoretical framework of the study followed by the methodology. Thereafter the results of the study are presented and discussed. The article closes with conclusions and recommendations.

\section{Trends from the research literature}

Over the years, both managers and researchers have enquired why employees leave organisations (Adams \& Beehr, 1998; Estryn-Behar et al., 2010). Organisational withdrawal is defined, for the purposes of this research, as a general construct, composed of a variety of acts or intentions that reflect both the negative attitudes of the job and the target of these negative attitudes. Two forms of organisational withdrawal have been empirically distinguished: job withdrawal and work withdrawal. Job withdrawal reflects 'employees' efforts to remove themselves from a specific organisation and their work role', and work withdrawal refers to the efforts of employees 'to avoid specific aspects of their specific work role' (Adams \& Beehr, 1998; Hanisch \& Hulin, 1991).

This paper focuses on two types of job withdrawal: occupational turnover and early retirement. Occupational turnover is defined as leaving a profession, while early retirement refers to leaving a position or a career path before normal retirement age (Hanisch \& Hulin, 1990, 1991). Occupational turnover and early retirement can be imposed or voluntary; in this study, the focus is on the latter. Both occupational turnover and early retirement are longlasting psychological processes (Beehr, 1986). The NEXTstudy showed that, for the majority of the nurses who left the profession, serious consideration of leaving began in the year which preceded eventual leaving (Flinkman et al., 2010; Hasselhorn et al., 2005). The retirement process takes place years before and after the actual exit from working life. Therefore, retirement can be seen as an ongoing process rather than a discrete event (Beehr, 1986; Taylor \& Shore, 1995). Long before employees actually retire they start to develop representations of their future experiences, as retirees, and start to consider when to retire (Beehr, 1986). These representations and intentions are influenced by many factors, such as labour market opportunities and social security rules and also individual and social variables (Zappalà, Depolo, Fraccaroli, Guglielmi \& Sarchielli, 2008).

Factors influencing the job withdrawal process are classified in many ways. Beehr (1986) identified three main dimensions influencing the retirement process: (1) personal, (2) workrelated and (3) environmental. A simpler distinction is based on work-related and non-work dimensions. Work-related factors refer, for example, to autonomy, skill variety and task significance whereas non-work characteristics are related to personal obligations such as having to care for a sick family member or an enthusiasm to engage in personal hobbies (Beehr, Glazer, Nielson \& Farmer, 2000). The decision to leave the profession and the decision to retire early are both likely to be the result of a process with numerous simultaneous underlying causes, so-called 'push' and 'pull' factors (Beehr et al., 2000; Hayes et al., 2006). Push factors are adversely perceived aspects of a job that cause employees to want to end their current employment (e.g. conflicts at work or ill health), and pull factors are attractive external incentives, such as university studies or early retirement opportunities (Estryn-Behar et al., 2010; Schultz, Morton \& Weckerle, 1998). However, employees perceive these pushes and pulls in different contexts and therefore the same event may be rated as either a push or pull for different employees (Schultz et al., 1998). It is suggested that the choice employees make between these two forms of intended job withdrawal is dependent on the level of desirability of these options, and also the factors that cause the form of withdrawal more likely to happen in a particular situation (Adams \& Beehr, 1998; Hanisch \& Hulin, 1991).

On the personal level, age is a factor that influences withdrawal by limiting the options available to the employee (Adams \& Beehr, 1998). An inverse relationship between age and turnover has been demonstrated in previous studies concerning the nurses' intentions to leave the profession (Flinkman et al., 2010; Hayes et al., 2006). The tendency for employees to consider retirement increases as they age (Lehto \& Sutela, 2008; Von Bonsdorff, 2009). However, there are also studies which have demonstrated that older employees plan to retire later than expected (Adams, 1999; Zappala et al., 2008). Taylor and Shore (1995) argue that young respondents may be less realistic about the retirement decision than those who are closer to the retirement age.

Deteriorating health has consistently been an important predictor that signals the decision to retire early (Beehr, 1986; Elovainio et al., 2005; Von Bonsdorff, 2009). It has been suggested that poor health limits an employee's ability to 
perform their job and to remain in their role at work (Hanisch \& Hulin, 1991). In recent studies the concept of work ability has been applied to indicate the balance between the demands required by the job and the employee's personal resources, consisting of health, ability, education, competence, values and attitudes (Camerino et al., 2008; Ilmarinen, 2006). Results from the NEXT-study have shown that low work ability is associated with the intention to leave the nursing profession (Camerino et al., 2008).

It has been suggested that women are more likely to choose professional change or retirement because they typically have more discontinuous work histories, lower tenure and lower pay (Adams \& Beehr, 1998). However, several studies have demonstrated that male nurses have a greater intention to leave the profession than female nurses (Flinkman et al., 2010; Hasselhorn et al., 2005; Hintsala, 2005). In addition, children, spouses and ageing parents are seen to affect the work and turnover habits of nurses, possibly leading to a change in the working environment (Flinkman et al., 2010; Hayes et al., 2006). Gender has been included in many studies concerning early retirement, but the results are mixed (Zappala et al., 2008). Talaga and Beehr (1995) have found that for older men and women, traditional gender roles explained some of their retirement decisions. The number of dependents increased the odds of retirement for women and decreased the odds for men (Talaga \& Beehr, 1995). However, a study among Finnish health care and social employees found no gender differences in the consideration of early retirement (Elovainio et al., 2005).

The dissatisfaction with salary or low pay may contribute to a nurse's intention behind occupational turnover (Flinkman et al., 2010; Hayes et al., 2006). Flinkman et al. (2008) found that dissatisfaction with their salary was one of the most important reasons for young (under 30) Finnish nurses to consider ending their nursing career. Income is also one of the strongest predictors of the decision to retire (Beehr et al., 2000). Previous studies have demonstrated that those who have greater financial security generally retire at an earlier age (Adams, 1999; Taylor \& Shore, 1995). For example, Zappalá et al. (2008) found that income per se did not affect the employees' retirement decision, but this decision was rather affected by the adequacy of the financial situation for retirement.

Educational level is believed to have an impact on the nurses' intention behind turnover: better educated nurses are more likely to leave their current organisation in order to seek career advancement, especially if there are limited career opportunities in their current organisation (Flinkman et al., 2010; Hayes et al., 2006). In Finland, numerous studies have shown that the risk of early retirement is higher among staff with lower levels of education (Forma, Tuominen, Tuominen \& Väänenen-Tomppo, 2006; Järnefelt, 2010). The pattern is similar in all European Union countries and additionally in the United States (Järnefelt, 2010).
The central element of the organisational withdrawal model is the notion that both turnover and early retirement are enacted in response to work-related attitudinal antecedents, especially job satisfaction and organisational commitment (Adams \& Beehr, 1998; Mathieu \& Zajac, 1990). Job satisfaction is conceptualised as the individual's opinion about how well personal expectations at work correspond to outcomes. Job satisfaction has been considered in empirical studies to be either an overall feeling about the job (global approach) or a related set of attitudes about different aspects of the job (facet approach) (Coomber \& Barriball, 2007). In this study the global approach is used, because the interest was in overall job satisfaction. Organisational commitment has been characterised by three factors: firstly, a strong belief in and acceptance of the organisation's goals and values, secondly, a willingness to exert a considerable effort on behalf of the organisation, and thirdly, a strong desire to maintain membership in the organisation (Mowday, Steers \& Porter, 1979). Previous studies have demonstrated that younger nurses tend to report lower organisational commitment than older nurses (Flinkman et al., 2008; Laine, 2005; Salminen, 2009).

Earlier studies have consistently reported that job satisfaction and organisational commitment are key antecedents of employee turnover (Mathieu \& Zajac, 1990; Peterson, 2004). Price and Mueller (1981) have viewed turnover as a product of job satisfaction and organisational commitment, which in turn are influenced by personal, organisational (such as opportunities for training and development) and environmental factors (such as alternative job opportunities outside the organisation) (Hayes et al., 2006). Organisational withdrawal theory suggests that the same antecedents should be found for retirement, but the empirical data are somewhat more mixed (Adams \& Beehr, 1998; Hanisch \& Hulin, 1991). On the basis of earlier studies it is assumed that job satisfaction and organisational commitment are negatively related to both occupational turnover and retirement intentions. However, because retirement involves withdrawal from working life and an entirely new lifestyle with different societal norms, it is possible that the relationship of job satisfaction and organisational commitment to early retirement intentions, will be weaker than is found for their relationship to the intentions for occupational turnover (Adams \& Beehr, 1998).

In the field of Human Resource Management (HRM) the mechanisms through which HR practices may influence the retention of ageing and younger nurses, are rarely studied (Armstrong-Stassen \& Schlosser, 2010). However, it has been found that HR practices that demonstrate investment in employees and recognition of their contributions signal an organisation's support for, and commitment to, its employees. From a social exchange perspective, employees respond to the organisation's actions by continuing their participation in the organisation (Armstrong-Stassen, 2008). At the individual level, HR practices are considered to have an impact on an employee's evaluation of management policies and practices, which in turn will affect the employees' behaviour and their personal feelings of job satisfaction and well-being (Guest, 1999). 
Access to training and development activities are seen as one means by which the organisation communicates the value it places on the employees' contribution, which in turn can enhance motivation and commitment to the organisation (Patrickson \& Hartmann, 1995). For example, poor development opportunities have been associated with the nurses' intentions to leave the profession (Flinkman et al., 2008; Hasselhorn et al., 2005). Although social exchange studies have not been concerned specifically with older employees, it is arguable that HR practices, targeted to the needs of older employees, may serve as a signal to older employees that the organisation values their contribution and older employees respond by remaining with their organisation (Armstrong-Stassen, 2008). Previous studies imply that having a reasonable amount of occupational competence is related to a nurse's well-being and also to his or her employability (Van der Heijden et al., 2010). It can also be assumed that older employees with obsolete skills are the most likely to retire early (Armstrong-Stassen \& Schlosser, 2007; Beehr, 1986).

An ideal work environment emphasises opportunities for learning and development included with opportunities for participative decision making (Karasek \& Theorell, 1990; Lavoie-Tremblay et al., 2006). Karasek's (1979) Job DemandControl Model specifies two independent inputs influencing job strain: job demands (the amount of work, complexity of work and time constraints) and control of the work situation (the capacity to apply one's qualifications and develop new job skills, and the authority of employees to make decisions concerning their work). According to this model, job strain and related health problems occur in situations where high demands coincide with low control. On the other hand, high demand together with high decision latitude can lead to the positive learning of new skills and behaviours (Elovainio et al., 2005). Recent studies have shown that among nurses dissatisfaction was an important work-related reason for their occupational turnover. Dissatisfaction involved the lack of application of their abilities, a lack of autonomy and difficulties with working hours (Estryn-Behar et al., 2010; Flinkman et al., 2010). Work that required much physical effort and that involved repetitive tasks exhausted the employees and may have lead them to consider early retirement (Beehr et al., 2000; Zappalá et al., 2008). For example, poor job control and high job demands have been found to increase the likelihood of Finnish health care and social employees considering early retirement (Elovainio et al., 2005).

\section{Research objectives}

The objective of this study is twofold. First, it examines the intentions of younger and ageing registered nurses to leave the nursing profession and their intentions to retire early. Registered nurses refer to persons who have a valid qualification and are registered by the National Supervisory Authority for Welfare and Health (Valvira). In Finland, the nursing profession is regulated by law and working as a nurse requires authorisation (In Working as a registered nurse in Finland. (n.d.). Retrieved from http:/ / www.valvira.fi/en/licensing/professional_practice_ rights/nurses). In this study the distinction between younger and ageing employees rests on a definition based on chronological age, and the age of 45 is adopted as a starting point when referring to ageing employees, which is in line with previous studies (Camerino et al., 2008; Ilmarinen, 2006). Secondly, this study investigates how nurses' perceptions of their development opportunities and job control, together with other work-related and personal factors, are associated with the intentions for job withdrawal. Work-related variables are expected to explain additional variance over and above personal variables in the intention to leave the profession and the intention to retire early.

\section{The potential value-add of the study}

Previous studies, concerning the intentions of nurses' that have resulted in a high job turnover, have mostly focused on organisational turnover (Hayes et al., 2006; Irvine \& Evans, 1995; Price \& Mueller, 1981). There is little evidence of the factors associated with the nurses' occupational turnover (Flinkman et al., 2010; Hasselhorn et al., 2005). However, investigating the nurses' intentions to leave the profession is important because withdrawal from the profession reduces the number of nurses in the field (Flinkman et al., 2010; Van der Heijden et al., 2009). In order to prevent nursing shortages it is also important to investigate the nurses' early retirement intentions and understand what work-related factors contribute to the decision to retire early (Van der Heijden, Schalk \& Van Veldhoven, 2008). There is a need for retention strategies that favour both ageing and younger nurses (Lavoie-Tremblay et al., 2006). Only a few studies have combined their investigations into forms of job withdrawal, the intention to leave the profession and the intention to take early retirement (Hanisch \& Hulin, 1990, 1991). This paper seeks to fill this gap.

\section{Research design Research approach}

A quantitative research approach was followed in the execution of the study. The data were collected at a single point-of-time, with the primary aim of identifying the significant personal and work-related factors associated with intentions for job withdrawal. The study described in this paper is part of a broader Age Management research project, conducted in the School of Business and Economics at the University of Jyväskylä in Finland.

\section{Research method \\ Research participants}

The study population consisted of 896 registered nurses working in a public university hospital located in Northern Savo, Finland. The registered nurses participating in the study were permanently or temporarily employed and they worked in surgical wards or in internal medicine. Nurses holding a managerial position were excluded from the study. The sampling was systematic: every fifth nurse was 
left out. The systematic sampling left us with a total of 747 nurses who actually participated in the study. The response rate was $46.1 \%(N=343)$. No questionnaires were rejected because they were all fully completed. The study design allowed us to analyse the demographic data (age, gender, form of employment) of the non-respondents. No statistically significant differences were detected between respondents and non-respondents regarding demographic data, which meant that no systematic bias occurred among nurses participating in the study. The demographic characteristics of the respondents are presented in Table 1 .

The mean age of the respondents was 41.2 years and the age range was from 23 to 59 years. Age was categorised into four groups: under $35(n=94), 35-44(n=119), 45-54$ $(n=104)$ and over $54(n=26)$. The majority of the respondents were female (92\%). Sixty percent of the respondents worked in the surgical wards and the rest worked in the internal medicine unit. Most of the nurses worked in rotating shifts (79\%) and most of them were permanently employed (76\%). The majority of those who were employed on a temporary basis were younger employees (under 45 ) and there was a statistical difference between the form of employment and the age groups $\left(\chi^{2}=96.790, d f=3, p<0.001\right)$. The educational background of the respondents was recoded into two groups: college level registered nurse education (79\%) and a Bachelor's degree in nursing (21\%). Most of the younger respondents had the higher level of education and most of the older respondents had the lower level. The relationship between education and age was statistically significant $\left(\chi^{2}=61.350, d f=3, p<0.001\right)$. The difference in educational level between the younger and ageing nurses is explained by the fact that in the 1990s the nursing education changed from college level to Bachelor's degree in Finland (Råholm, Larsen Hedegaard, Löfmark \& Slettebø, 2010).

\section{Measuring instruments}

The questionnaire was developed by three researchers of the Age Management research project, and it was the same as one used in an earlier Age Management survey in another Finnish hospital (Salminen, 2009). Every researcher had her own research interest (training and development, rewarding and leadership) and she was responsible for questions and scales related to her own topic, but the outcome variables (job withdrawal intentions, organisational commitment and job satisfaction) were determined and selected together. The questionnaire was piloted four months earlier and nine randomly selected younger and ageing nurses, from both surgical wards and the internal medicine unit, completed the questionnaire and concluded that all the questions were comprehensible. The questionnaire firstly addressed demographics (age, gender, marital status, education, pay, form of employment, shift work, number of children, the field of patient care), followed secondly by work-related variables.

The intention to leave the nursing profession was measured with one question: 'How often have you thought about giving
TABLE 1: Demographic characteristics of the respondents $(N=343)$.

\begin{tabular}{llll}
\hline Demographic characteristics & Category & \% & $\boldsymbol{n}$ \\
\hline Age group & under 35 & 27 & 94 \\
& $35-44$ & 35 & 119 \\
& $45-54$ & 30 & 104 \\
& over 54 & 8 & 26 \\
Gender & female & 92 & 315 \\
& male & 8 & 28 \\
Educational background & College level registered nurse & 79 & 271 \\
& education & & \\
Form of employment & Bachelors degree in nursing & 21 & 72 \\
& Permanent & 76 & 261 \\
Shift work & Temporary & 24 & 82 \\
\hline Field of patient care & No & 21 & 72 \\
& Yes & 79 & 271 \\
\hline
\end{tabular}

$n$, given as frequency.

up nursing completely?' The question was a modified version of one used in the NEXT-study (Hasselhorn, Tackenberg \& Müller, 2003; Hasselhorn et al., 2005). The specific time period (during the past 12 months), which was used in the original question, was excluded because the aim of this study was to examine and compare the current intentions regarding both forms of job withdrawal. Previous studies have also demonstrated that the consideration process of occupational turnover (Flinkman et al., 2010; Hasselhorn et al., 2005) and retirement (Beehr, 1986; Taylor \& Shore, 1995) differ in the length of time of each. The intentions for early retirement were also measured with one question: 'How often have you thought about seeking retirement before your full retirement age?' The question was based on the questions used in earlier Finnish studies (Elovainio et al., 2005; Lehto \& Sutela, 2004). There was a minor modification of the wording concerning the early retirement question, to render it congruent with the occupational turnover question. In both questions the scale ranged from 1 to 5, 1 'never', 2 'a few times a year', 3 'a few times a month', 4 'a few times a week' and 5 'every day'.

Job satisfaction was measured with one question: 'How satisfied are you in your present work?' (Lehto \& Järnefelt, 2000). The five-point response scale varied from very dissatisfied $(1)$ to very satisfied $(5)($ mean $=3.54, \mathrm{SD}=1.00)$.

The organisational commitment scale consisted of six Likert scale items. The scale was a reduced version of the original organisational commitment scale (Porter, Steers, Mowday \& Boulian, 1974; Tuomi \& Vanhala, 2002). Organisational commitment was characterised by three factors: firstly, a strong belief in and acceptance of the organisation's goals and values, secondly, the willingness of the employee to exert considerable effort on behalf of the organisation, and thirdly, a strong desire to maintain membership in the organisation. Two items indicated each of these three factors. The sum variable included all six items (mean $=2.88, \mathrm{SD}=0.72$, coefficient $\alpha=0.77$ ).

The nurses' estimation of their work ability was indicated with one question from the Work Ability Index (Tuomi, 
Ilmarinen, Jahkola, Katajarinne \& Tulkki, 2002). Nurses were asked to estimate their current work ability compared to their lifetime best. This single-item question has been found to correlate highly with the entire Work Ability Index, and is therefore a reliable measure of self-rated work ability (Tuomi et al., 2002). The scale varied from 0 to 10, with 10 indicating work ability at its best (mean $=8.33, \mathrm{SD}=1.42$ ).

The development opportunities scale consisted of four items. Respondents were asked to consider what kind of opportunities they have in their present job for: (1) training that promotes their professional skills, (2) self development, (3) career progress and (4) learning new things at their workplace. The items were based on earlier Finnish studies (Lehto \& Järnefelt, 2000; Tuomi \& Vanhala, 2002). A fivepoint response scale was used for these items, varying from very poor (1) to very good (5). A sum variable called 'development opportunities' was formed from these four items (mean $=3.21, \mathrm{SD}=0.58$, coefficient $\alpha=0.77$ ).

The job control scale was a reduced version of Karasek's (1979) Job Demand-Control Model (Elovainio et al., 2005; Lehto \& Järnefelt, 2000). Job control was measured as the extent to which nurses felt free to determine the quantitative and qualitative factors of their own work process. Controllability was measured using eight items. Respondents were asked about their opportunities to determine (1) their working methods, (2) the pace at which they worked, (3) how work was shared among the staff, (4) who they worked with, (5) procedures at work, (6) the content of their work, (7) the objectives of their work and (8) working hours. The scale anchors were 1 'not at all', 2 'to a limited extent', 3 'quite a lot', 4 'considerably' (mean $=2.1, \mathrm{SD}=0.49$, coefficient $\alpha=0.81$ ).

Nurses were also asked to indicate what they perceived their competence level to be, to perform their job. The response scale was (1) 'I need additional training in order to perform well in my present job', (2) 'my skills are in balance with present work demands', (3) 'I have the potential to carry out more challenging tasks' (Lehto \& Järnefelt, 2000).

Some of the scales were modified to fit the purpose of the study, while others were adapted without changes. The questionnaire was piloted by a group of nurses in an effort to establish its validity. The reliability of the sum variables were shown to be satisfactory, with alpha coefficients larger than 0.70 (Nunnally \& Bernstein, 1994). However, questionnaire items as short as one sentence, asked as criteria for measuring the intentions for job withdrawal and job satisfaction, could have weakened the reliability of these instruments.

\section{Research procedure}

The permission to conduct the study was obtained from the Ethical Committee of the hospital. Questionnaires were distributed via the hospital's internal post to the nurses in March 2005. The internal post was used because the researchers did not have the respondents' home addresses.
Each respondent received a personalised envelope (name and station of ward) containing a questionnaire and a return envelope. The confidentiality of the study was guaranteed in the covering letter. The covering letter indicated the purpose of the study and included instructions for answering the questions. Participation in the study was voluntary. Consent was assumed when respondents returned a completed questionnaire. Respondents had the right to withdraw at any stage in the research process. Each questionnaire was coded to preserve anonymity whilst allowing researchers to identify non-returns. The response rate was $46.1 \%(N=343)$.

\section{Statistical analysis}

The statistical analyses were carried out with SPSS 18.0. The $\chi^{2}$-test was used to examine the differences between younger and ageing nurses regarding their intention to leave the nursing profession and their intention to retire early. The five-point response scale to job withdrawal intentions was dichotomised: those who have frequent thoughts of leaving (a few times a month or more often) and those who consider leaving a few times a year or not at all. It could be regarded as natural for most professional people to consider leaving their job a few times a year (Estryn-Behar et al., 2010; Flinkman et al., 2008). In correlation analysis the original scale of the job withdrawal intentions was used. Logistic regression analyses were performed to estimate the strength of the association between independent variables (personal and workrelated variables) and dependent variables (job withdrawal intentions).

\section{Results}

The frequent intention to leave the profession, for the overall sample, was $25 \%(n=86)$ (Table 2). Almost one in five $(19 \%$, $n=65$ ) nurses had frequently (a few times a month or more often) thought about early retirement. The $\chi^{2}$-test showed that there was a statistical difference between age groups and their intention to give up nursing $\left(\chi^{2}=13.296, d f=3\right.$, $p=0.004$ ). The youngest nurses (under 35) thought most often about leaving the profession whereas the oldest nurses (over 54) considered early retirement. The relationship between age groups and the intention to take early retirement was statistically significant $\left(\chi^{2}=10.466, d f=3, p=0.015\right)$.

The descriptive statistics, means, standard deviations, reliability estimates, and Spearman's rho correlations for the variables are reported in Table 3. The Cronbach coefficients were over 0.70, which are acceptable (Nunnally \& Bernstein, 1994).

TABLE 2: Age groups and frequent intentions for job withdrawal.

\begin{tabular}{lcccccc}
\hline Age groups & \multicolumn{2}{c}{$\begin{array}{c}\text { Frequent intention to } \\
\text { leave the profession }\end{array}$} & & \multicolumn{2}{c}{$\begin{array}{c}\text { Frequent intention } \\
\text { to retire early }\end{array}$} \\
\cline { 2 - 3 } \cline { 6 - 7 } & $\mathbf{\%}$ & $\boldsymbol{n}$ & & $\mathbf{\%}$ & $\boldsymbol{n}$ \\
\hline Under 35 & 37 & 34 & & 9 & 8 \\
$35-44$ & 27 & 32 & & 23 & 27 \\
$45-54$ & 17 & 17 & & 22 & 22 \\
Over 54 & 12 & 3 & & 31 & 8 \\
\hline Total & $\mathbf{2 5}$ & $\mathbf{8 6}$ & & $\mathbf{1 9}$ & $\mathbf{6 5}$ \\
\hline
\end{tabular}

$n$, given as frequency. 
The intention to leave the profession and the intention to take early retirement were positively and significantly correlated $(r=.407, p<0.01)$. Concerning personal variables, age correlated negatively with the intention to leave the profession $(r=-.239, p<0.01)$ and positively with the intention to retire early $(r=.210, p<.01)$. With work-related variables, the strongest negative correlation was found between job satisfaction and the intention to leave the profession $(r=-.459, p<0.01)$. There was also a strong negative correlation between organisational commitment and the intention to leave the profession $(r=.424$, $p<0.01)$. Work ability, job control and perceived development opportunities had negative correlations with both forms of job withdrawal intention.

Two logistic regression analyses were conducted to examine the factors associated with the intention to leave the profession and the intention to retire early. The predictive power of the variables is indicated with multivariate odds ratios. Table 4 shows that from the personal variables, only age was significantly associated with intentions to leave the profession. In other words, older age decreased the odds ratio for the intentions to leave the profession ( $\mathrm{OR}=0.926)$. From the work-related variables, work ability, job satisfaction and organisational commitment, these turned out to be significantly associated with the intentions for occupational turnover. Good work ability (OR = 0.657), high job satisfaction $(\mathrm{OR}=0.459)$ and high organisational commitment $(\mathrm{OR}=0.376)$ decreased the likelihood of intentions for occupational turnover. In addition, those who had skills that were balanced with their present work demands ( $\mathrm{OR}=7.277)$, or who judged that they had the potential to carry out more challenging tasks $(\mathrm{OR}=13.176)$, had an increased likelihood of intending to leave the profession. The Nagelkerke R-square of 0.43 indicates the amount of variation in the dependent variable accounted for by the model (Pallant, 2005).

As is evident in Table 5, age, gender and shift work were the only personal variables that were significantly associated with intentions to retire early. Older age increased the odds ratio $(\mathrm{OR}=1.081)$, whereas, being female $(\mathrm{OR}=0.226)$ and not working in shifts $(\mathrm{OR}=0.331)$ decreased the odds ratio of intentions for early retirement. As far as work-related variables were concerned, work ability, job satisfaction and job control were significantly related to the intention to retire early. Better work ability $(\mathrm{OR}=0.837)$, higher job satisfaction $(\mathrm{OR}=0.520)$ and higher job control $(\mathrm{OR}=0.199)$ decreased the risk of intended early retirement. The Nagelkerke R-square was 0.33 .

\section{Discussion}

The main objective of this study was to examine the factors associated with the intentions for occupational turnover and early retirement, with special reference to perceived development opportunities and job control. Given the global shortage of registered nurses, understanding the antecedents of the intentions for job withdrawal is of great importance. In this study, the actual withdrawal decisions or transitions were not studied. However, behavioural intentions are found to be significantly related to actual behaviours, and they are therefore an ideal substitute when time constraints prevent the measurement of the actual behaviours (Hanisch \& Hulin, 1990). This has been shown in both occupational turnover (Flinkman et al., 2010) and retirement literature (Adams \& Beehr, 1998).

The results showed that a quarter of the nurses who participated in the study had frequently thought about

TABLE 3: Means, standard deviations, reliability estimates and bivariate correlations for the variables.

\begin{tabular}{|c|c|c|c|c|c|c|c|c|c|c|c|c|c|c|}
\hline Variables & Mean & SD & $\alpha$ & 1 & 2 & 3 & 4 & 5 & 6 & 7 & 8 & 9 & 10 & 11 \\
\hline $\begin{array}{l}\text { 1. Intention to leave the } \\
\text { profession }\end{array}$ & 2.10 & 1.61 & - & & & & & & & & & & & \\
\hline 2. Intention to retire early & 1.19 & 1.06 & - & $\begin{array}{l}.407 * * \\
(n=338)\end{array}$ & & & & & & & & & & \\
\hline 3. Age & 41.15 & 9.20 & - & $\begin{array}{l}-.239 * * \\
(n=339)\end{array}$ & $\begin{array}{l}.210 * * \\
(n=338)\end{array}$ & & & & & & & & & \\
\hline 4. Number of children & 1.79 & 1.24 & - & $\begin{array}{l}-.036 \\
(n=300)\end{array}$ & $\begin{array}{l}.104 \\
(n=299)\end{array}$ & $\begin{array}{l}.372 * * \\
(n=302)\end{array}$ & & & & & & & & \\
\hline 5. Pay & 2067.67 & 322.51 & $\begin{array}{l}- \\
-\end{array}$ & $\begin{array}{l}-.011 \\
(n=309)\end{array}$ & $\begin{array}{l}.019 \\
(n=308)\end{array}$ & $\begin{array}{l}.161^{* *} \\
(n=312)\end{array}$ & $\begin{array}{l}.040 \\
(n=277)\end{array}$ & & & & & & & \\
\hline 6. Work ability & 8.33 & 1.42 & $\begin{array}{l}- \\
-\end{array}$ & $\begin{array}{l}-.170 * * \\
(n=337)\end{array}$ & $\begin{array}{l}-.300 * * \\
(n=336)\end{array}$ & $\begin{array}{l}-.272^{* *} \\
(n=341)\end{array}$ & $\begin{array}{l}-.141 * \\
(n=300)\end{array}$ & $\begin{array}{l}.036 \\
(n=310)\end{array}$ & & & & & & \\
\hline 7. Job satisfaction & 3.54 & 1.00 & $\begin{array}{l}- \\
-\end{array}$ & $\begin{array}{l}-.459 * * \\
(n=337)\end{array}$ & $\begin{array}{l}-.268^{* *} \\
(n=336)\end{array}$ & $\begin{array}{l}.052 \\
(n=338)\end{array}$ & $\begin{array}{l}.045 \\
(n=298)\end{array}$ & $\begin{array}{l}.008 \\
(n=308)\end{array}$ & $\begin{array}{l}.260 * * \\
(n=336)\end{array}$ & & & & & \\
\hline $\begin{array}{l}\text { 8. Organisational } \\
\text { commitment }\end{array}$ & 2.88 & 0.72 & 0.77 & $\begin{array}{l}-.424 * * \\
(n=330)\end{array}$ & $\begin{array}{l}-.163^{* *} \\
(n=329)\end{array}$ & $\begin{array}{l}.209 * * \\
(n=333)\end{array}$ & $\begin{array}{l}.102 \\
(n=293)\end{array}$ & $\begin{array}{l}-.034 \\
(n=303)\end{array}$ & $\begin{array}{l}.180 * * \\
(n=331)\end{array}$ & $\begin{array}{l}.517^{* *} \\
(n=329)\end{array}$ & & & & \\
\hline $\begin{array}{l}\text { 9. Perceived development } \\
\text { opportunities }\end{array}$ & 3.21 & 0.58 & 0.77 & $\begin{array}{l}-.179 * * \\
(n=332)\end{array}$ & $\begin{array}{l}-.123^{*} \\
(n=332)\end{array}$ & $\begin{array}{l}-.010 \\
(n=336)\end{array}$ & $\begin{array}{l}-.067 \\
(n=295)\end{array}$ & $\begin{array}{l}-.102 \\
(n=305)\end{array}$ & $\begin{array}{l}.169 * * \\
(n=334)\end{array}$ & $\begin{array}{l}.361^{* *} \\
(n=331)\end{array}$ & $\begin{array}{l}.374^{* *} \\
(n=327)\end{array}$ & & & \\
\hline 10. Job control & 2.10 & 0.49 & 0.81 & $\begin{array}{l}-.262 * * \\
(n=331)\end{array}$ & $\begin{array}{l}-.229 * * \\
(n=330)\end{array}$ & $\begin{array}{l}-.004 \\
(n=3319\end{array}$ & $\begin{array}{l}.048 \\
(n=292)\end{array}$ & $\begin{array}{l}.028 \\
(n=304)\end{array}$ & $\begin{array}{l}.148 * * \\
(n=329)\end{array}$ & $\begin{array}{l}.329 * * \\
(n=330)\end{array}$ & $\begin{array}{l}.369 * * \\
(n=322)\end{array}$ & $\begin{array}{l}.316^{* *} \\
(n=324)\end{array}$ & & \\
\hline $\begin{array}{l}\text { 11. Competence at doing } \\
\text { one's job }\end{array}$ & 2.22 & 0.69 & - & $\begin{array}{l}.172 * * \\
(n=337)\end{array}$ & $\begin{array}{l}.016 \\
(n=336)\end{array}$ & $\begin{array}{l}.037 \\
(n=341)\end{array}$ & $\begin{array}{l}.068 \\
(n=300)\end{array}$ & $\begin{array}{l}.006 \\
(n=310)\end{array}$ & $\begin{array}{l}.146 * * \\
(n=339)\end{array}$ & $\begin{array}{l}-.102 \\
(n=336)\end{array}$ & $\begin{array}{l}-.019 \\
(n=331)\end{array}$ & $\begin{array}{l}-.091 \\
(n=334)\end{array}$ & $\begin{array}{l}-.012 \\
(n=329)\end{array}$ & \\
\hline
\end{tabular}

SD, standard deviation.

*, $p<0.05 ; * *, p<0.01$ 
TABLE 4: Logistic regression analysis of the intention to leave the profession.

\begin{tabular}{|c|c|c|c|c|c|c|}
\hline Independent variables & $\beta$ & SE $\beta$ & $\begin{array}{c}\text { Wald's } \\
\chi^{2}\end{array}$ & $d f$ & Sig. & $\begin{array}{c}\operatorname{Exp}(\beta) \\
\text { (odds ratio) }\end{array}$ \\
\hline Age & -0.077 & 0.030 & 6.399 & 1 & 0.011 & 0.926 \\
\hline Gender & -0.644 & 0.618 & 1.084 & 1 & 0.298 & 0.525 \\
\hline Education & 0.527 & 0.545 & 0.933 & 1 & 0.334 & 1.694 \\
\hline Form of employment & -0.155 & 0.506 & 0.093 & 1 & 0.760 & 0.857 \\
\hline Shift work & -0.031 & 0.498 & 0.004 & 1 & 0.950 & 0.969 \\
\hline Number of children & 0.194 & 0.182 & 1.130 & 1 & 0.288 & 1.214 \\
\hline Pay & -0.001 & 0.001 & 0.984 & 1 & 0.321 & 0.999 \\
\hline Work ability & -0.420 & 0.161 & 6.793 & 1 & 0.009 & 0.657 \\
\hline Job satisfaction & -0.778 & 0.228 & 11.692 & 1 & 0.001 & 0.459 \\
\hline Organisational commitment & -0.978 & 0.346 & 8.007 & 1 & 0.005 & 0.376 \\
\hline Perceived development opportunities & 0.701 & 0.382 & 3.370 & 1 & 0.066 & 2.015 \\
\hline Job control & -0.521 & 0.463 & 1.263 & 1 & 0.261 & 0.594 \\
\hline Need for additional training (reference category) & - & - & 9.667 & 2 & 0.008 & - \\
\hline Potential to carry out more challenging tasks & 2.578 & 0.836 & 9.503 & 1 & 0.002 & 13.176 \\
\hline Constant & -1.093 & 0.146 & 56.404 & 1 & 0.000 & 0.335 \\
\hline
\end{tabular}

Overall model evaluation: Chi-square $\chi^{2} 86.487, d f=14, p=0.000$; Cox and Snell $R^{2}=0.291$; Nagelkerke $R^{2}=0.431 ;$ Hosmer and Lemeshow test $\chi^{2}=11.224, d f=8, p=0.189$.

$\beta$, Coefficients; SE $\beta$, Standard Error Coefficients; Wald's $\chi^{2}$, a Wald statistic with a chi-square distributione; $d f$, degrees of freedom; Sig, significance; Exp $(\beta)$, odds ratio.

TABLE 5: Logistic regression analysis of the intention to retire early

\begin{tabular}{|c|c|c|c|c|c|c|}
\hline Independent variables & $\beta$ & SE $\beta$ & $\begin{array}{c}\text { Wald's } \\
\chi^{2}\end{array}$ & $d f$ & Sig. & $\begin{array}{c}\operatorname{Exp}(\beta) \\
\text { (odds ratio) }\end{array}$ \\
\hline Age & 0.077 & 0.030 & 6.514 & 1 & 0.011 & 1.081 \\
\hline Gender & -1.488 & 0.657 & 5.125 & 1 & 0.024 & 0.226 \\
\hline Education & 0.838 & 0.659 & 1.620 & 1 & 0.203 & 2.313 \\
\hline Form of employment & -0.274 & 0.528 & 0.269 & 1 & 0.604 & 0.760 \\
\hline Shift work & -1.105 & 0.521 & 4.492 & 1 & 0.034 & 0.331 \\
\hline Number of children & 0.011 & 0.169 & 0.004 & 1 & 0.948 & 1.011 \\
\hline Pay & -0.001 & 0.001 & 3.761 & 1 & 0.052 & 0.999 \\
\hline Work ability & -0.177 & 0.145 & 1.493 & 1 & 0.022 & 0.837 \\
\hline Job satisfaction & -0.653 & 0.230 & 8.063 & 1 & 0.005 & 0.520 \\
\hline Organisational commitment & 0.188 & 0.381 & 0.244 & 1 & 0.621 & 1.207 \\
\hline Perceived development opportunities & 0.338 & 0.353 & 0.916 & 1 & 0.339 & 1.402 \\
\hline Job control & -1.613 & 0.506 & 10.180 & 1 & 0.001 & 0.199 \\
\hline Need for additional training (reference category) & - & - & 4.571 & 2 & 0.102 & - \\
\hline Potential to carry out more challenging tasks & 1.042 & 0.644 & 2.622 & 1 & 0.105 & 2.836 \\
\hline Constant & -1.416 & 0.159 & 79.118 & 1 & 0.000 & 0.243 \\
\hline
\end{tabular}

Overall model evaluation: Chi-square $\chi^{2} 58.023, d f=14, p=0.000$; Cox and Snell $R^{2}=0.206$; Nagelkerke $R^{2}=0.329$; Hosmer and Lemeshow test $\chi^{2}=6.147, d f=8, p=0.601$.

$\beta$, Coefficients; SE $\beta$, Standard Error Coefficients; Wald's $\chi^{2}$, a Wald statistic with a chi-square distributione; $d f$, degrees of freedom; Sig, significance; Exp $(\beta)$, odds ratio.

leaving the profession. This finding supports the work of previous Finnish researchers (Flinkman et al., 2008; Kuokkanen et al., 2003). Almost a fifth of the nurses had frequently thought about taking early retirement. A recent national study, in Finland, demonstrated that approximately $30 \%$ of Finnish nurses considered themselves unable to work until the retirement age, for health reasons (Laine et al., 2011). This finding, that intentions for job withdrawal were age dependent, is supported by previous studies (Flinkman et al., 2010; Hayes et al., 2006; Lehto \& Sutela, 2008). Those who considered leaving the nursing profession were in the younger age group, while those who considered early retirement were in the older age group.

There were both similarities and differences in the factors associated with the intentions for job withdrawal. Work ability was associated with both forms of job withdrawal intention. This finding is in line with earlier studies (Camerino et al., 2008; Von Bonsdorff, Koponen \& Aaltio, 2009). In other words, the result suggests that an imbalance between personal resources and the demands of the job forced the nurses to consider occupational turnover or early retirement. This is not surprising, because the nursing profession is both mentally and physically demanding (Van der Heijden et al., 2009).

In line with previous studies, this study showed that job satisfaction had an important role in both forms of job withdrawal intention (Hasselhorn et al., 2005; Kuokkanen et al., 2003). The result supports the basic assumption that when nurses are satisfied with their jobs, they are less likely to consider leaving them. However, organisational commitment was only associated with the intentions for occupational turnover. 
This study showed that poor job control increased the likelihood of thoughts about early retirement. This finding offers support for the results of previous research (Elovainio et al., 2005; Von Bonsdorff et al., 2009). However, job control was not associated with the intentions for occupational turnover. Surprisingly, perceived development opportunities were also not associated with the intentions for occupational turnover, although some earlier studies have shown that poor development opportunities are related to the nurses' intentions to leave the profession (Hasselhorn et al., 2005; Hayes et al., 2006). One explanation for this result is that the perceived development opportunities were operationalised with only four items in this study. A larger scale could have given a more accurate picture of the perceived development opportunities. However, it should be noted that perceived development opportunities were positively correlated with job satisfaction, which in turn was associated with both forms of job withdrawal intention. This lends support for Price and Mueller's (1981) turnover model, which states that job satisfaction and organisational commitment moderate the relationship between organisational factors, such as development opportunities and turnover intentions. Armstrong-Stassen and Schlosser (2010) have also pointed out that HR practices may have relatively distal rather than immediate influences on the decision of individuals to remain with their organisation.

With regards to competence at performing one's job, the likelihood of leaving the profession was greater for those who had their skills in balance with their present work demands, or who judged that they had the potential to carry out more challenging tasks. Dissatisfaction of a nurse, with the use of his or her abilities and skills have been shown, in previous studies, to be an important work-related factor associated with the nurse's intention to leave the profession (Estryn-Behar et al., 2010; Flinkman et al., 2010).

\section{Conclusion}

The nurses' occupational turnover represents a major problem in health care organisations concerning recruitment costs, organisational continuity, the ability to care for patients and the quality of care given (Flinkman et al., 2010; Hayes et al., 2006). High rates of occupational turnover may also discourage prospective students from joining the profession in the first place (Jourdain \& Chênevert, 2010). Early retirement is yet another factor contributing to the problem of a shortage of nurses. In many countries two measures that have been implemented to address this problem are recruiting nurses from overseas, and increasing the enrolment of students in schools of nursing (Blakeley \& Ribeiro, 2008). However, there is also the need to implement retention strategies, which equally favour younger and ageing nurses (Lavoie-Tremblay et al., 2006). Recognising the antecedents of both occupational turnover and early retirement can help organisations to redesign work and HR practices, in order to keep both younger and ageing nurses in their profession.
The results of this study have some practical implications for preventing the trend of job withdrawal. Firstly, this study highlights the importance of job satisfaction amongst the nurses who were studied. It seems that job dissatisfaction was one factor contributing to the nurses' occupational turnover and intentions for early retirement. Therefore, the health care organisation should pay attention to factors influencing the nurses' job satisfaction in order to prevent premature loss of capable and knowledgeable nurses, and to secure health services in the future. The nurses' intentions for job withdrawal and job satisfaction should be regularly evaluated in order to prevent them leaving the profession prematurely.

Secondly, the findings also indicate that promoting work ability is an important factor to prevent both forms of job withdrawal. Attention should also be paid to the competencies of the nurses. This means matching skills and abilities with the demands of the job (Ilmarinen, 2006). Those nurses, who consider that they have the potential to carry out more challenging tasks, should be offered opportunities to utilise their skills and competencies. In line with previous studies, the results seem to suggest that making work more controllable and increasing personal autonomy, especially amongst the ageing nurses, can increase their ability to cope at work until retirement age (Blakeley \& Ribeiro, 2008; Elovainio et al., 2005; Lavoie-Tremblay et al., 2006).

\section{Limitations}

The results of this study should be interpreted in the light of the study's limitations. Firstly, caution is required when generalising the results, because of the rather low response rate $(46.1 \%)$, and the fact that this study was restricted to one Finnish university hospital. It should also be noted that the study was cross-sectional. A longitudinal study is needed in order to confirm the causal directions between the antecedents and the intentions for job withdrawal (Adams \& Beehr, 1998).

The second limitation concerns the use of one sentence items for measuring constructs. In the future there will be a need to strengthen these instruments. Another weakness of this study is that the roles of occupational commitment and affective organisational commitment were not studied, even though previous studies have emphasised their importance in the decision to leave one's profession (Laine, 2005; Van der Heijden et al., 2009) and in the decision to retire early (Adams, 1999).

There may be a common-method bias because, in this study, self-reported measures were used for all the study variables (Podsakoff, McKenzie, Lee \& Podsakoff, 2003). The development opportunities and job control were studied from the subjective experience of nurses, which may only partly reflect the actual situation. However, it is true that peoples' perceptions of what their organisation is doing will play an important role in their decision to remain with or to leave their organisation (Armstrong-Stassen, 2008). 
Finally, the full age range of the sample was used in the analyses because the study focused on both occupational turnover and early retirement. However, theoretical and empirical knowledge tells us that younger nurses are more likely to leave their profession and older nurses are more like to retire early (Flinkman et al., 2010; Hayes et al., 2006; Von Bonsdorff, 2009). When these two forms of job withdrawal intention are studied separately, a more age-restricted sample should be used (Adams \& Beehr, 1998).

\section{Recommendations}

Some suggestions for future research are offered. Firstly, it must be acknowledged that both occupational turnover and early retirement have multiple antecedents. Therefore one question for further study is how other HR practices are associated with intentions for job withdrawal. Secondly, it would be interesting to investigate the role of managerial support associated with job withdrawal intentions. Previous studies have suggested that low leadership quality results in lower job satisfaction, which in turn predicts the nurses' intentions to leave the profession (Coomber \& Barriball, 2007; Hayes et al., 2006) and to retire early (Von Bonsdorff et al., 2009). Thirdly, more research is also needed into the role of factors outside the organisation, such as the labour market or family issues. One suggestion for future research is to focus on the nurses' career and career-related variables, because both occupational turnover and early retirement are often regarded as the outcome of a career decision-making process (Adams \& Beehr, 1998; Van der Heijden et al., 2009). Finally, a qualitative study approach could be used to derive a deeper understanding of factors contributing to the nurses' intentions for job withdrawal.

\section{Acknowledgements}

An earlier version of this article was presented at the 26th Workshop on Strategic Human Resource Management in May 2011 in Reykjavik, Iceland. The author would like to thank the Ellen and Artturi Nyyssönen Foundation and the Foundation for Economic Education for funding the writing of this study.

\section{Competing interests}

The author declares that she has no financial or personal relationship(s) which may have inappropriately influenced her in writing this paper.

\section{References}

Adams, G.A. (1999). Career related variables and planned retirement age: An extension of Beehr's model. Journal of Vocational Behavior, 55(2), 221-235. http://dx.doi.org/10.1006/jvbe.1998.1679

Adams, G.A., \& Beehr, T.A. (1998). Turnover and retirement: A comparison of their similarities and differences. Personnel Psychology, 51, 643-665. http://dx.doi. org/10.1111/j.1744-6570.1998.tb00255.x

Armstrong-Stassen, M. (2008). Human resource management practices for mature workers and why aren't employers using them? Asia Pacific Journal of Human Resources, 46, 334-352. http://dx.doi.org/10.1177/1038411108091755

Armstrong-Stassen, M., \& Schlosser, F. (2007). Benefits of a supportive development climate for older workers. Journal of Managerial Psychology, 23(4), 419-437. http://dx.doi.org/10.1108/02683940810869033
Armstrong-Stassen, M., \& Schlosser, F. (2010). When hospitals provide HR practices tailored to older nurses, will older nurses stay? It may depend on their tailored to older nurses, will older nurses stay? It may depend on their
supervisor. Human Resource Management Journal, 20(4), 375-390. http://dx.doi. supervisor. Human Resource Management
org/10.1111/j.1748-8583.2010.00143.x

Beehr, T.A. (1986). The process of retirement: A review and recommendations for future investigation. Personnel Psychology, 39, 31-55. http://dx.doi. org/10.1111/j.1744-6570.1986.tb00573.x

Beehr, T.A., Glazer, S., Nielson, N.L., \& Farmer, S.J. (2000). Work and nonwork predictors of employees' retirement ages. Journal of Vocational Behavior, 57(2), 206-225. http://dx.doi.org/10.1006/jvbe.1999.1736

Blakeley, J.A., \& Ribeiro, V.E.S. (2008). Early retirement among registered nurses: Contributing factors. Journal of Nursing Management, 16, 29-37. http://dx.doi. org/10.1111/j.1365-2934.2007.00793.x, PMid:18211333

Buchan, J., \& Calman, L. (2004). The global shortage of registered nurses: An overview of issues and actions. Geneva: International Council of Nurses.

Camerino, D., Conway, P.M., Van der Heijden, B.I.J.M., Estryn-Behar, M., Costa, G. \& Hasselhorn, H.-M. (2008). Age-dependent relationships between work ability, thinking of quitting the job, and actual leaving among Italian nurses: A longitudinal study. International Journal of Nursing Studies, 45, 1645-1659. http://dx.doi. org/10.1016/j.ijnurstu.2008.03.002, PMid:18456268

Coomber, B., \& Barriball, K.L. (2007). Impact of job satisfaction components on intent to leave and turnover for hospital-based nurses: A review of the research interature. International Journal of Nursing Studies, 44, 297-314. http://dx.doi. literature. International Journal of Nursing Studies,
org/10.1016/j.ijnurstu.2006.02.004, PMid:16631760

Elovainio, M., Forma, P., Kivimäki, M., Sinervo, T., Sutinen, R., \& Laine, M. (2005). Job demands and job control as correlates of early retirement thoughts in Finnish social and health care employees. Work \& Stress, 19(1), 84-92. http://dx.doi. social and health care employees.
org/10.1080/02678370500084623

Eskola, K. (2007). län merkitys hoitajien, opettajien ja palomiesten työssä. [The meaning of age in the work of nurses, teachers and fire fighters]. In K. Kauppinen \& J. Evans (Eds.), MONIKKO - tasa-arvo monimuotoisissa työyhteisöissä [MONIKKO J. Evans (Eds.), MONIKKO-tasa-arvo monimuotoisissa tyoyhteisöissä [MONIKKO-
Equity in diverse work communities], (pp. 57-71). Retrieved September 19, 2011 Equity in diverse work communities], (pp. 57-71). Retrieved September 19, 2011,
from http://www.tasa-arvoklinikka.fi/tasa/images/stories/pdf/Monikko_kirja.pdf

Estryn-Behar, M., Van der Heijden, B.I.J.M., Fry, C., \& Hasselhorn, H-M. (2010). Longitudinal analysis of personal and work-related factors associated with
turnover among nurses. Nursing Research, 59(3), 166-177. http://dx.doi. turnover among nurses. Nursing Research, 59(3),
org/10.1097/NNR.0b013e3181dbb29f, PMid:20421841

Flinkman, M., Laine, M., Leino-Kilpi, H., Hasselhorn, H.-M., \& Salanterä, S. (2008). Explaining young registered Finnish nurses' intention to leave the profession: A questionnaire survey. International Journal of Nursing Studies, 45, 727-739. http://dx.doi.org/10.1016/j.ijnurstu.2006.12.006, PMid:17280674

Flinkman, M., Leino-Kilpi, H., \& Salanterä, S. (2010). Nurses' intention to leave the profession: Integrative review. Journal of Advanced Nursing, 66(7), 1422-1434. http://dx.doi.org/10.1111/j.1365-2648.2010.05322.x, PMid:20497270

Forma, P., Tuominen, E., Tuominen, K., \& Väänänen-Tomppo, I. (2006). Sukupuoli ja aiottu eläkeikä [Gender and intended retirement age]. In A-M. Lehto, H. Sutela \& A. Miettinen (Eds.), Kaikilla mausteilla. Artikkeleita työolotutkimuksesta. [With all ingredients. Articles about the working condition studies], (pp. 203-222). Studies 244. Helsinki: Statistics Finland.

Guest, D.E. (1999). Human resource management - The workers verdict. Human Resource Management Journal, 9(3), 5-25. http://dx.doi. org/10.1111/j.1748-8583.1999.tb00200.x

Hanisch, K.A., \& Hulin, C.L. (1990). Job attitudes and organisational withdrawal: An examination of retirement and other withdrawal behaviors. Journal of Vocational Behavior, 37, 60-78. http://dx.doi.org/10.1016/0001-8791(90)90007-O

Hanisch, K.A., \& Hulin, C.L. (1991). General attitudes and organisational withdrawal: An evaluation of a causal model. Journal of Vocational Behavior, 39, 110-128. http://dx.doi.org/10.1016/0001-8791(91)90006-8

Hasselhorn, H.-M., Tackenberg, P., \& Müller, B.H. (Eds.). (2003). Working conditions and intent to leave the profession among nursing staff in Europe. Report No 7:2003. Stockholm: SALTSA.

Hasselhorn, H.-M., Müller, B.H., \& Tackenberg, P. (Eds.). (2005). NEXT Scientific Report July 2005. Retrieved September 12, 2011, from http://www.next.uni-wuppertal. de/EN/index.php?articles-and-reports/

Hayes, L.J., O'Brien-Pallas, L., Duffield, C., Shamian, J., Buchan, J., Hughes, F. et al. (2006). Nurse turnover: A literature review. International Journal of Nursing Studies, 43, 237-263. http://dx.doi.org/10.1016/j.ijnurstu.2005.02.007, PMid:15878771

Hietaniemi, M., \& Ritola, S. (Eds.). (2007). The Finnish pension system. Handbooks 2007:6. Finnish Centre for Pensions. Retrieved September 10, 2011, from http:// www.etk.fi/Binary.aspx?Section $=44670 \&$ Item $=60250$ /

Hintsala, A. (2005). Autonomia ammatista poistumisen ennakoijana hoitotyössä Nais- ja mieshoitajien arviointia ja vertailua päätöksenteosta, pätevyydestä, työn tärkeydestä ja johtamisesta hoitotyössä. [Autonomy anticipating career change in nursing. Female and male nurses' assessment and comparison of decisionmaking, competence, importance of work and leadership in nursing]. Doctoral dissertation. Publications, E. Social Sciences 117. Kuopio: Kuopio University.

Ilmarinen, J. (2006). Towards a longer worklife - Ageing and the quality of worklife in the European Union. Helsinki: Finnish Institute of Occupational Health.

Irvine, D.M., \& Evans, M.G. (1995). Job satisfaction and turnover among nurses: Integrating research findings across studies. Nursing Research, 44(4), 246-253. PMid:7624236

Järnefelt, N. (2010). Education and longer working lives. A longitudinal study on education differences in the late exit from working life of older employees in Finland. Doctoral dissertation. Finnish Centre for Pensions, Studies 2010:1. Helsinki: Finnish Centre for Pensions. 
Jourdain, G., \& Chênevert, D. (2010). Job demands-resources, burnout and intention to leave the nursing profession: A questionnaire survey. International Journal of Nursing Studies, 47, 709-722. http://dx.doi.org/10.1016/j.ijnurstu.2009.11.007, Pursing Studies,

Karasek, R.A. (1979). Job demand, job decision latitude, and mental strain: Implication for job redesign. Administrative Science Quarterly, 24(2), 285-308. http://dx.doi. org/10.2307/2392498

Karasek, R.A., \& Theorell, T. (1990). Healthy work, stress, productivity, and the reconstruction of working life. New York: Basic Books.

Kuokkanen, L., Leino-Kilpi, H., \& Katajisto, J. (2003). Nurse empowerment, jobrelated satisfaction, and organisational commitment. Journal of Nursing Car Quality, 18(3), 184-192. http://dx.doi.org/10.1097/00001786-200307000-00004, PMid:12856902

Laine, M., Kokkinen, K., Kaarlela-Tuomaala, A., Valtanen, E., Elovainio, M., Keinänen, M. et al. (2011). Sosiaali-ja terveysalan työolot 2010. [The working conditions and well-being of social and health care staff 2010]. Helsinki: Finnish Institute of and well-being of social
Occupational Health.

Laine, M. (2005). Hoitajana huomennakin. Hoitajien työpaikkaan ja ammattiin sitoutuminen. [Organisational and professional commitment of nurses]. Doctora dissertation. Annales Universitatis Turkuensis C 233. Turku: University of Turku.

Lavoie-Tremblay, M., O’Brien-Pallas, L., Viens, C., Brabant, L.H., \& Gélinas, C. (2006) Towards an integrated approach for management of ageing nurses. Journal of Nursing Management, 14, 207-212. http://dx.doi.org/10.1111/j.1365 2934.2006.00604.x, PMid:16600009

Lehto, A.-M., \& Järnefelt, N. (Eds.). (2000). Jaksaen ja joustaen. Artikkeleita työolotutkimuksesta. [Managing and bending. Essays of the working conditions]. Helsinki: Statistics Finland.

Lehto, A.-M., \& Sutela, H. (2004). Uhkia ja mahdollisuuksia. Työolotutkimusten tuloksia 1977-2003. [Threats and opportunities. Studies of the working conditions 19772003]. Helsinki: Statistics Finland.

Lehto A.-M., \& Sutela, H. (2008). Työolojen kolme vuosikymmentä. Työolotutkimusten tuloksia 1977-2008. [Three decades of working conditions. Studies of the working conditions 1977-2008]. Helsinki: Statistics Finland.

Mathieu, J.E., \& Zajac, D.M. (1990). A review and meta-analysis of the antecedents, correlates, and consequences of organisational commitment. Psychological Bulletin, 108, 171-194. http://dx.doi.org/10.1037/0033-2909.108.2.171

Mowday, R.T., Steers, R.M., \& Porter, L.W. (1979). The measurement of organisational commitment. Journal of Vocational Behavior, 14, 224-247. http://dx.doi. commitment. Journal of Vocation
org/10.1016/0001-8791(79)90072-1

Nunnally, J.C., \& Bernstein, I.H. (1994). Psychometric theory. (3rd edn.). New York: McGraw-Hill.

Pallant, J. (2005). SPSS survival manual. (2nd ed.). London: Open University Press.

Patrickson, M., \& Hartmann, L. (1995). Australia's ageing population: Implications for human resource management. International Journal of Manpower, 16(5/6) for human resource management. International Journal

Peterson, S.L. (2004). Toward a theoretical model of employee turnover: A human resource development perspective. Human Resource Development Review, 3(3) 209-227. http://dx.doi.org/10.1177/1534484304267832

Podsakoff, P.M., MacKenzie, S.B., Lee, J.Y., \& Podsakoff, N.P. (2003). Common method biases in behavioral research: A critical review of the literature and recommended remedies. Journal of Applied Psychology, 88, 879-903. http:// dx.doi.org/10.1037/0021-9010.88.5.879, PMid:14516251

Porter, L.W., Steers, R.M., Mowday, R.T., \& Boulian, P.V. (1974). Organisational commitment, job satisfaction and turnover among psychiatric technicians. Journa of Applied Psychology, 59(5), 603-609. http://dx.doi.org/10.1037/h0037335
Price, J.L., \& Mueller, C.W. (1981). A causal model of turnover for nurses. Academy of Management Journal, 24(3), 543-565. http://dx.doi.org/10.2307/255574, PMid:10252608

Råholm, M-B., Larsen Hedegaard, B., Löfmark, A., \& Sletteb $\varnothing$, Å. (2010). Nursing education in Denmark, Finland, Norway and Sweden - From Bachelor's degree to PhD. Journal of Advanced Nursing, 66(9), 2126-2137. PMid:20626496

Salminen, H. (2009). Access to learning - focus on ageing Finnish nurses. Lifelong Learning in Europe 4/2009, 216-224.

Schultz, K.S., Morton, K.R., \& Weckerle, J.R. (1998). The influence of push and pull factors on voluntary and involuntary early retirement decision and adjustment. Journal of Vocational Behavior, 53, 45-57. http://dx.doi.org/10.1006/ jvbe.1997.1610

Talaga, J.A., \& Beehr, T.A. (1995). Are there gender differences in predicting retirement decisions? Journal of Applied Psychology, 80(1), 16-28. http://dx.doi. org/10.1037/0021-9010.80.1.16, PMid:7706191

Taylor, M.A., \& Shore, L. (1995). Predictors of planned retirement age: An application of Beehr's model. Psychology and Ageing, 10(1), 76-83. http://dx.doi. org/10.1037/0882-7974.10.1.76, PMid:7779319

Tuomi, K., \& Vanhala, S. (Eds.). (2002). Yrityksen toiminta, menestyminen ja henkilöstön hyvinvointi. Seurantatutkimus metalliteollisuudessa ja vähittäiskaupan alalla. [Firm's performance, success and well-being of the personnel. A follow-up study in the metal industry and in the retail sector]. Studies B 40. Helsinki: Helsink School of Economics.

Tuomi, K., Ilmarinen, J., Jahkola, A., Katajarinne, L., \& Tulkki, A. (2002). Work Ability Index. (2nd rev. edn.). Occupational Health Care No. 19. Helsinki: Finnish Institute of Occupational Health.

Tuominen, E. (2007). The role of pension policy in promoting longer working careers of older people. Working Papers 2007:3. Helsinki: Finnish Centre for Pensions.

Van der Heijden, B.I.J.M., Schalk, R., \& Van Veldhoven, M.J.P.M. (2008). Ageing and careers: European research on long-term career development and early retirement. Career Development International, 13(2), 85-94. http://dx.doi. org/10.1108/13620430810860512

Van der Heijden, B.I.J.M., Van Dam, K., \& Hasselhorn, H.M. (2009). Intent to leave nursing. The importance of interpersonal work context, workhome interference, and job satisfaction beyond the effect of occupational commitment Career Development International, 14(7), 616-635. http://dx.doi. org/10.1108/13620430911005681

Van der Heijden, B.I.J.M., Kummerling, A., Van Dam, K., Van der Schoot, E., EstrynBehar, M., \& Hasselhorn, H.M. (2010). The impact of social support upon intention to leave among female nurses in Europe: Secondary analysis of data from the NEXT survey. International Journal of Nursing Studies, 47, 434-445. http://dx.doi. org/10.1016/j.ijnurstu.2009.10.004, PMid:19909953

Von Bonsdorff, M.E. (2009). Intentions of early retirement and continuing work among middle-aged and older employees. Doctoral dissertation. Jyväskylä Studies in Business and Economics 83. Jyväskylä: University of Jyväskylä.

Von Bonsdorff, M.E., Koponen, S., \& Aaltio, I. (2009). Staying in working life? Early retirement intentions among public sector nurses. In M. Beisheim, F. Maier, L. Kreil \& B. Gusenbauer (Eds.), Constructions of women's age in the workplace, (pp. 31-53). Frankfurt am Main: Peter Lang.

Working as a registered nurse in Finland. (n.d.). Retrieved November 18, 2011, from http://www.valvira.fi/en/licensing/professional_practice_rights/nurses

Zappalà, S., Depolo, M., Fraccaroli, F., Guglielmi, D., \& Sarchielli, G. (2008). Postponing job retirement? Psychological influences on the preference for early or late retirement. Career Development International, 13(2), 150-167. http://dx.doi. org/10.1108/13620430810860558 